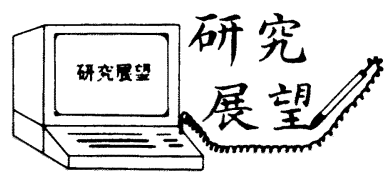

日本機械学会論文集 $(\mathrm{A}$ 編) 72 巻 717 号 $(2006-5)$

\title{
ナノスケールの材料カ学*
}

三 浦 英 生 ${ }^{* 1}$

\section{Materials and Mechanics in Nano Scale}

\author{
Hideo MIURA*2 \\ ${ }^{* 2}$ Fracture and Reliability Research Institute, Graduate School of Engineering, Tohoku University, \\ 6-6-11-712 Aoba, Aramaki, Aoba-ku, Sendai-shi, Miyagi, 980-8579 Japan
}

Key Words : Structural Reliability, Residual Stress, Reliability, Micromechanics, Material Testing, Thin Film

\section{1.はじめに}

ナノテクノロジーの発展に伴い, 材料寸法の微細化 が進み, 半導体デバイスや磁気へッドあるいは光ディ スクなど, 最先端の薄膜応用製品では $1 \mathrm{~nm}$ 以下の寸 法制御で構造あるいは情報の最小単位が製造されてい る(1).このような製品では構造単位を形成する原子数 が数百から数万個と, 正に数えることが可能な世界に 入っている．製造方法にもアトミックマニュピレーシ ヨンが導入されつつあり, 原子 1 個単位の組成制御が 視野に入りつつある。このような世界では, 材料の物 性が単なる平均的な化学組成では議論できず, 局所的 な原子配列で決定されることになる，結晶欠陥や不純 物の混入も含め 1 原子単位の構造変化がその局所的な 物性を支配することになる。したがって，空間的な物 · 性分布の存在が材料あるいは構造の使用段階で顕在化 することになり, この空間分布を考慮した信頼性設計 が不可欠となる.

材料寸法の微細化は，このようなバルク的な結晶組 成分布のみでなく，材料の物性がバルク的な性質より もむしろ表面や界面の影響を受け決定されることを意 味している. 最も単純な構造がカーボンナノチューブ であり, 全原子が表面を形成しているという特徴的な 構造をもつことで, 従来にはない強度物性や電磁気的 な物性が発現していることは周知のとおりであ る(2) (4). さらに, 多くの製品においては複数の材料が 積層されて構造が形成されることから, 異種材料界面

* 原稿受付 2006 年 2 月 27 日

*1 正員, 東北大学大学院工学研究科( $\mathbf{9} 980$-8579 仙台市青葉 区荒巻字青葉 6-6-11-712)

E-mail : hmiura @ rift.mech.tohoku.ac.jp
の存在が積層構造全体の物性を支配する場合がある. これは, 異種材料間の格子不整合の存在により, 材料 単体のバルク状態とは大きく異なる原子配列(規則)が 準安定的に存在するためである. 材料強度の世界で最 も顕著な現象が, 多くの積層材料系で確認されている 数\%にも達する弾性ひずみや数 GPa に達する応力の 残留である(5). 材料の薄膜化によりバルク材料と比較 して結晶の純度が向上していることも強度向上の一翼 を担っているものと考えられるが, 界面の存在による 原子移動の拘束が見氺けの強度を向上させ，バルク材 料の破壊強度の数十から数百倍に達する応力・ひずみ が安定に存在しているものと考えられる. 場合によっ ては結晶形態 (原子配列) が基板(下地材料)の配列に拘 束され，バルク材料では存在し得ない原子配列が実現 する場合もあり，バルク特性からまったく異なる材料 物性が発現する場合もある。

ナノテクノロジーの進歩は, このような研究対象と なる材料寸法の微細化のみではなく，分析・計測技術 の空間分解能向上によるバルク構造材料の破壊現象解 明寸法の微細化という発展にも寄与している. 構造材 料におけるき裂の発生と進展挙動解明は安全で安心な 社会構築のために重要な研究課題の一つであるが, こ れまではバルク材料の強度試験を繰返し, 分布幅が存 在する点在デー夕を統計的に処理し代表(平均)特性を 論じてきた。しかし実際の設計段階では, 分布幅の支 配因子も十分には解明されてはいないため，この代表 特性に大きな安全率をかけることで信頼性を保証せざ るを得ないのが実情である.

しかし，分析・計測技術の進歩によりき裂先端にお けるき裂の進展メカニズム解明研究が進展し, 破壊の 支配因子が原子レベルで明らかにされはじめている. 
これにより，科学的な合理性をもって破壊現象のばら つきやゆらぎ(分布) 発生メカニズムが解明され, 破壊 を防止する材料あるいは環境制御因子が明らかにされ るものと期待されている. 現在, 高経年化した大型工 ネルギー関連機器では定量的余寿命評価に基づく維持 管理方法の確立が求められており, この分野では緊急 課題にもなっている.さらに, 破壞の予兆となる材料 の損傷過程解明も進むことで, 材料劣化の早期診断も 可能になるものと考光られる。 そこで本報ではナノス ケール領域における材料力学研究の現状と今後の期待 について紹介する。

\section{2. 微細化に伴う材料強度物性の変化}

微細化による強度物性変化の最も顕著な材料として カーボンナノチューブを挙げることができることはす でに周知のとおりである。 また，使用する材料寸法そ のものは微細化しなくても, 結晶組織をナノメートル スケールで制御することで強度向上が図られた例とし て, 金属ナノガラス ${ }^{(6)}$ や高純度鉄(7) などを挙げること もできる。このように材料寸法や組織をナノスケール で制御することで, 元素構成に変化を与えなくても 「新材料」の創成が可能となっている。すなわち, 従 来のバルク特性とは大きく異なる物性を実現すること が可能となりつつある。したがって，化学記号は同一 でも, 従来の常識とは大きく異なる材料が今後は多数 現れる可能性がある.

単純な寸法の微細化を考元ても相対的に表面に存在 する原子の構成比率が高くなり, 材料の全自由エネル ギー中に占める表面エネルギーの影響度合いが高くな ることでさまざまな物性変化が生じえる。例えば室温 では脆性挙動を示すシリコン結晶もナノメートルの寸 法領域では明りょうな塑性変形挙動を示すことなどが 報告されている(8). また, 寸法が微細化することで, バルク材料では実現困難な結晶組織が形成されること で大きな物性変動が生じる場合もある。

具体的な一例として, 薄膜化に伴う材料の強度物性 変化測定例を紹介する。材料を薄膜化するには多く方 法を選択することができる。従来の材料製造方法でも 使用されている圧延でも厚さ数 $\mu \mathrm{m}$ の金属箔を製造す ることは複数の金属材料で可能である。いわゆる薄膜 の製造方法として広く使用されているのはスパッタリ ング法で, 比較的低温で薄膜の形成が可能であり，か つ複雑な合金系でもその組成維持が容易であることか ら多くの金属材料で使用されている，また，一部の金 属ではめっき法も材料表面への皮膜形成に使用されて いる. 以上のすべての方法を使用して薄膜化が可能な

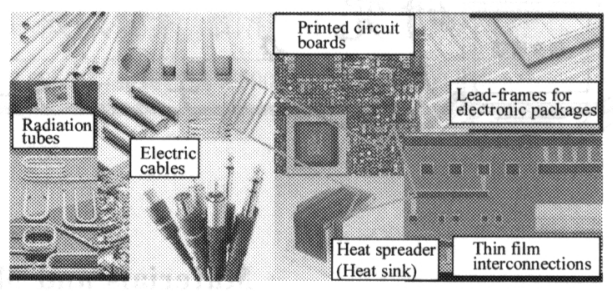

Fig. 1 Expanding application of copper materials

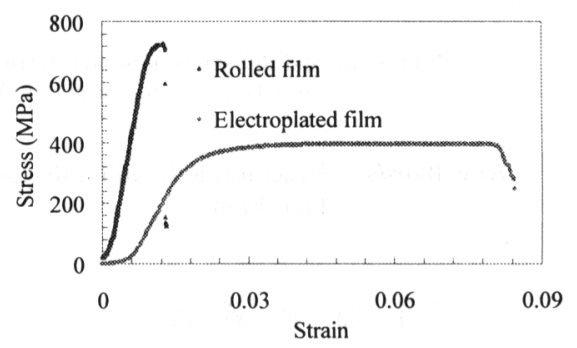

Fig. 2 Example of stress-strain curves of copper thin films

材料の一つに銅がある.銅はその高熱伝導性や低電気 抵抗かつ低コストという特長から最も多用されている 金属の一つである。従来は図 1 亿も示すように放熱管 や電気ケーブルに多用されてきた。さらに今後は, 電 子部品搭載用のプリント基板や半導体デバイス用の薄 膜配線材料として活用されはじめている。後者の応用 では, その寸法が数 $\mu \mathrm{m}$ から数十 $\mathrm{nm}$ となるため,い わゆる薄膜の製造方法として先に述べたスパッタリン グ法やめっき法が使用されている(9).

このような従来法と比較して新しい方法で製造した 銅薄膜の強度物性が従来のバルク材料から著しく変化 する場合があることが明らかになっている。薄膜化し た銅の応力ーひずみ曲線の測定例を図 2 に示す(10). 本 測定例では, 厚さが同じ $10 \mu \mathrm{m}$ の銅薄膜を圧延法とめ っき法で作製し，膜面内方向に引張試験を実施してい る. 両薄膜とも特に積極的に添加物等は導入していな い. 圧延銅とめっき銅では弾性率, 引張強度, 破断ひ ずみいずれの值も相互に大きく異なることが明らかに なっている。引張強度は約 2 倍, 破断ひずみも約 6 倍 異なっている。また, 弾性率はバルク銅の約 $130 \mathrm{GPa}$

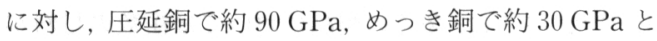
それぞれバルク材料と比較して大きく減少している. 同様敒試験を実施した，スパッタリング法で作製した 銅薄膜の弾性率は約 $130 \mathrm{GPa}$ とバルク材料と同等の 特性を示すことも確認されている。したがって, 銅薄 膜の機械特性 (強度物性) はその製造方法に依存して大 


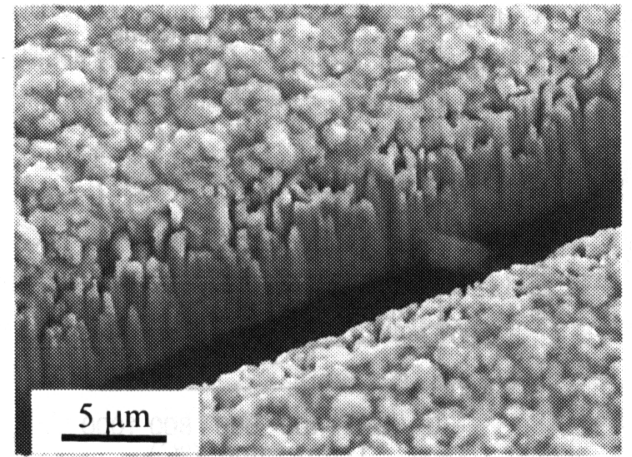

Fig. 3 Cross $^{-}$sectional texture of an electroplated copper thin film

きく変化することが明らかになっている.

化学的な材料組成に顕著な相違は認められてはいな いので, この強度物性の変化は結晶構造の変化に依存 したものと考えられる。材料の破壊強度は例えば平均 結晶粒径や結晶の配向性で変化することは知られてい るが, 図 2 のめつき膜のような著しい低弾性化や破断 伸びの急増はバルク材料で報告された事例はない.ま た，面心立方構造からなる銅のめつき膜の結晶配向性 はおもに(111) 結晶方位あるいは(110) 結晶方位となる ことが確認されているが，この結晶の配向性と図 2 に 示した応力ーひずみ挙動には特に相関性は認められな いとも確認されている。したがって,この大きな機械 特性の変化の主因は結晶の内部構造の変化ではないも のと考えられる.

めつき膜の断面結晶構造を走査型電子顕微鏡で観察 した例を図 3 に示す(10). 本測定例で使用しためつき。 膜は明確な柱状組織からなっていることが確認され

る. 平均粒径は数百 $\mathrm{nm}$ 程度の微細粒で膜の法線方向 に成長している。しかし, 各結晶粒間のいわゆる粒界 近傍はかなり粗な組織となっていることも確認され る.したがって, 本めっき膜では結晶粒界強度が従来 の多結晶材料と比較して弱くなっていることが推定さ れる.膜面内の引張試験環境では，この弱い粒界が主 として変形を担っていると考えると, 破断伸びの増加 も定性的には理解できる。また, 図 2 の応力ーひずみ 曲線では明確な加工硬化現象も認められないことか ら, 結晶内部での転位の発生と増殖, およびその拘束 という顕著な過程も発生しづらい環境にあることもこ のような推測を支持するものと考えている．いずれに しても, バルク材料では単純な柱状組織からなる構造 は存在しえないものでもあり，柱状組織における粒界 強度とその膜物性に及ぼす影響に関しては今後の重要

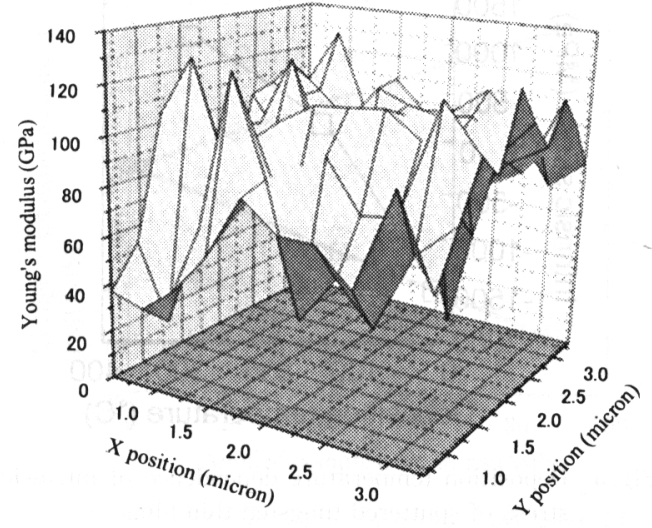

Fig. 4 Distribution of Young's modulus averaged in the depth of $50 \mathrm{~nm}$ from the surface of an electroplated copper thin film

な研究課題と考えられる(11).

なおこのような微視的な視点で材料の強度物性 (機械的特性)を論じると, 弾性率や破壊強度などのい わゆる材料定数は，薄膜内で空間的なゆらぎ(分布)を もつことになる，図 2 に示した応力ーひずみ曲線は薄 膜全体の平均的な特性を現したものであることは事実 である。しかし，めっき膜においては膜面内でこの特 性に大きな分布が存在していることも明らかになって いる. 図 4 にナノインデンテーション法を使用して膜 表面近傍(厚さ約 $50 \mathrm{~nm}$ ) の弾性率分布を著者らが測定 した例を示す。本測定例はわずか約 $3 \mu \mathrm{m}$ 角の領域を 測定したものであるが, 膜面内で弾性率が約 $10 \mathrm{GPa}$ から約 $130 \mathrm{GPa}$ までの大きな範囲で分布しているこ とがわかる。同様な測定をスパッタリング法で堆積し た薄膜で実施しても，その分布幅は $10 \mathrm{GPa}$ 程度であ ることが確認できているので，めっき法で作製した薄 膜はその内部に大きな機械的な特性分布が発生してい ることが明らかになっている。このような分布の存在 は緒言でも紹介したような高集積情報デバイスでは大 きな信頼性の低下を引き起こす危険性がある。したが ってこのような材料物性のゆらぎ(分布)の発生メカ二 ズムの解明とその制御方法の確立も重要な研究課題と なる。

\section{3. 異種材料界面近傍の強度物性変化}

ナノスケールで薄膜を積層する構造では, 異種材料 界面近傍における原子配列の乱れが強度物性にも著し い影響を与える場合がある。結晶格子の不整合は残留 ひずみや残留応力の発生原因になる．特に下地(基板) 材料が厚く，表面に形成(堆積)する薄膜の膜厚が十分 


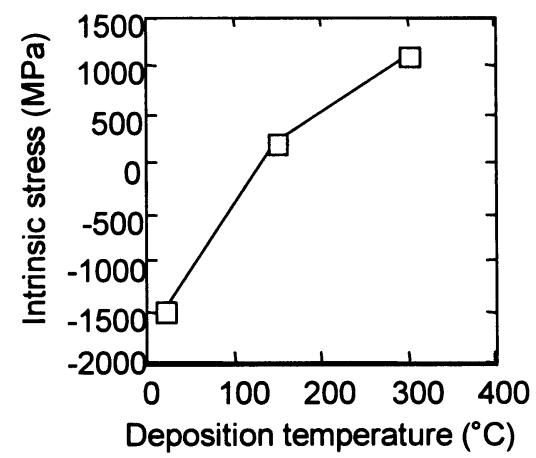

Fig. 5 Deposition temperature dependence of intrinsic stress of sputtered tungsten thin films

薄い場合には，緒言でも述べたように薄膜内部には 数\%あるいは数 GPa に達する残留ひずみや応力が発 生する場合がある。したがって, 見かけの強度はバル ク特性から大きく異なったものになる，さらに，薄膜 の堆積過程においては，その融点と比較して低温で原 子あるいは分子が堆積されることから, 熱力学的にか なり不安定な状態で原子結合が形成されるため, 結果 として高い応力やひずみが残留する．さらに，膜の熱 処理過程において体積変化が生じる場合には, 基板が その変化を拘束するためにやはり膜中には高い応力や ひずみが残留する場合がある，以上のような温度一定 の環境で発生する応力は総称として真性応力と呼ば れ，熱応力とは区別されている。ただし，その発生メ カニズムには多様性があり, 各薄膜の堆積条件に依存 して複雑に変化する. 以下で紹介する事例の真性応力 とは測定された残留応力から熱応力を差し引いた值で ある。

真性応力の顕著な発現事例を図 5 に示す．本事例は タングステン $(W)$ 薄膜をスパッタリング法で単結晶 シリコン基板上に堆積した場合の真性応力の膜堆積温 度依存性を測定したものである．タングステンは融点 が $3000^{\circ} \mathrm{C}$ 以上と高温で酸化されやすい材料であるた めスパッタリング法で低温成膜されることが多い. 本 測定例では，薄膜を堆積する基板の温度を制御し，そ の基板温度 (堆積温度) を室温 (約 $25^{\circ} \mathrm{C}$ ) から $300^{\circ} \mathrm{C}$ の間 で変化させるだけで, 堆積した薄膜中に真性応力起因 で残留する応力の值が, 圧縮の約 $1.5 \mathrm{GPa}$ から引張り の約 $1 \mathrm{GPa}$ まで符号も含めて大きく変化する.この ような符号も含めた大きな絶対値の残留応力変動は, 熱応力で説明することは困難であり, 薄膜固有の問題 と考えることができる．また，この絶対值は薄膜の堆 積䨌囲気や圧力等, 温度以外の関数でもあり, 発生メ

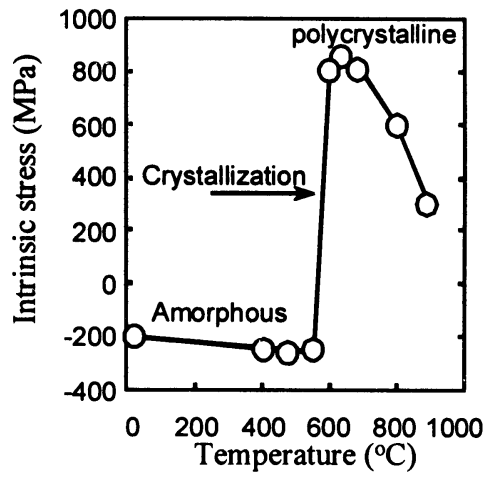

Fig. 6 Crystallization-induced stress of a silicon thin film

カニズムの詳細も解明されていないため, 実験デー夕 ベースを積み上げて使用しているというのが実情であ る.今後は発生メカニズムの解明とその定量的な制御 方法の確立が重要な課題となる。

同様に, 体積変化を伴う化学反応の過程で発生する 薄膜残留応力として, シリコン薄膜における結晶化反 応過程で測定された真性応力の事例を図 6 に示 す(12). 本事例ではシリコン薄膜をアモルファス構造 でシリコン単結晶基板上に堆積し, 約 $600^{\circ} \mathrm{C}$ 熱処理 で結晶化させている.シリコン薄膜をアモルファス状 態で形成するためには，相対的に低温でかつ高速に原 子(分子)を基板上に堆積する必要がある。このため, 一般的にアモルファスシリコン薄膜には圧縮応力が残 留する．結晶化反応過程ではアモルファス相と結晶相 の密度差(約 $0.7 \%$ )のため, 薄膜の体積収縮が発生す る.しかしこの体積収縮は基板で拘束されるため, 結 晶化した薄膜内部には高い引張応力が残留することに なる. 本事例では, 結晶化反応前後における残留応力 の変動幅は約 $1 \mathrm{GPa}$ に達している，結晶化後の応力 緩和はシリコンの粘弾性挙動あるいは塑性変形に伴う ものである．シリコンが室温近傍では脆性材料である ことや, $800^{\circ} \mathrm{C}$ 以上で明確な塑性変形を示し, 降伏応力 が数十 MPa 以下であるというバルク材料の性質から は,やはりこのような高い応力の発生や残留は説明が 困難である。

以上に示した事例からも明らかなように，薄膜材料 中にはバルク材料では安定に残留しえない高い応力が 発生し，かつ残留する。この残留応力の絶対值は熱応 力と比較して数十倍から数百倍にも達する場合もある ことから, 薄膜材料ではこの真性応力の定量的な把握 が信頼性の設計・評価という視点から極めて重要な課 題である。しかし，現状では，その発生メカニズムの 
詳細は解明されておらず，したがって，その制御方法 も理論的には確立されていない. 今後の材料力学分野 でやはり重要な研究課題の一つであると考えている.

\section{4. 物理化学現象に及ぼす残留応力・ひずみの影響}

これまで述べてきたように,ナノテクノロジーで活 用される薄膜材料の強度物性(機械的特性) は, バルク 材料のそれから大きく変化する場合が多い.また, 空 間的にもナノメートルのオーダでは大きな幅で各值に 分布が生じる場合もある. 特に, 高い応力やひずみが 発生あるいは残留することで, 他の物理化学現象にも 大きな影響を及ぼすことが明らかになっている。

高度情報通信社会の基盤インフラと考えることもで きる光通信用の半導体レーザや情報処理用の半導体デ バイスではすでにこの高い残留ひずみを活用してい る. 半導体レーザの発光波長は結晶のバンドギャップ で決定されるが, 実は光通信で使用されている約 1.55 $\mu \mathrm{m}$ の波長を有する安定して量産できる単体材料は存 在していない.このため格子定数の異なる複数の多元 素系の化合物半導体層を厚さ $1 \mathrm{~nm}$ あるいは $0.1 \mathrm{~nm}$ の単位で積層し, 所定のバンドギャップを創造してい $ろ^{(13)}$.この格子不整合の絶対值は数\%にも達してい るが, 各層の厚さを薄くし, かつ安定したひずみ勾配 が形成されるよう組成勾配も細かく制御することで転 位の発生等を極小化している.したがって, 半導体レ 一ザに扔いては, 発光波長の厳密な制御のためには残 留ひずみの制御が極めて重要な課題となっている.

さらに, 半導体デバイスでは, 積極的にシリコン結 晶をひずませることで理論限界を超える高速トランジ スタが実現されている(14). この場合も結晶をひずま・ せることで電子あるいは正孔のバンドギャップをシフ トさせ, それぞれの密度や有効質量を制御している. トランジスタ特性の応力(ひずみ)依存性測定例(15)を 図 7 に示す. 本測定例は, 既存の PMOS (正孔伝導型 Metal Oxide Semiconductor)トランジスタに, 四点 曲げ試験法を応用して一軸垂直応力(ひずみ) を負荷 し, トランジスタの代表性能であるコンダクタンス性 能を測定したものである。このようにトランジスタの 性能も応力(ひずみ)負荷により, 数十\%/100-MPaの 感度で変動する. 薄膜プロセスでは数百 MPa 以上相 当の応力を安定して残留させることが可能であること から，応力(ひずみ)制御のみでトランジス夕の性能を 理論限界 (無ひずみ時の特性という意味) の数倍も向上 させることが可能であり，実際に実現されている.

このように化学的には材料構成を一切変更すること なく，機械的な観点から応力・ひずみを制御するだけ

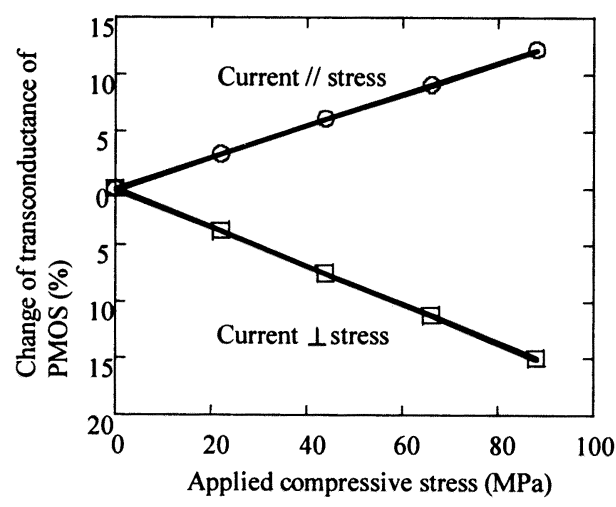

Fig. 7 Effect of stress on an electronic property of a transistor

で電磁気的な性能が著しく変化する場合がある。した がって, 薄膜材料あるいは異種材料を積層した薄膜構 造体の強度や応力ひずみ状態の評価あるいは設計制御 は, 材料力学的な視点からも新たな研究対象となり元 るものである.

さらに, 高い応力(ひずみ)が残留することで, 局所 的な化学反応も影響を受ける場合がある. 微小構造物 の世界では微小なシリコン結晶表面の熱酸化現象が局 所的な高い応力の発生で著しく変化することが明らか にされている. 具体的には, 化学反応の拡散定数 $D$ や界面反応係数が次式のように表現されている(16).

$$
D(T, \sigma)=D_{0} \exp \{-Q / k T\} \exp \{-\sigma V / k T\}
$$

ここで, $T$ は絶対温度, $\sigma$ は応力(あるいは圧力),$Q$ が従来の化学反応論における活性化エネルギー, $k$ は ボルツマン定数, $D_{0}$ は定数, $V$ は活性化体積と呼ば れる定数で, 応力の作用する領域を表す概念である. したがって本式は, 局所的な応力の作用で化学反応の 活性化エネルギーが実質的に変化することを意味して いる.この現象は要素実験からも実際の半導体デバイ スの製造プロセスにおける実測評価例(17) からも確認 されている.

このような局所的な高い応力の発生に伴う化学反応 の変化現象は, 必ずしも半導体デバイスのような微細 構造体に限定して生じるものではない。例えば, 構造 機器材料の信頼性を支配する応力腐食割れ現象におい ても,き裂先端におけるき裂進展現象は酸化反応によ り酸化皮膜の成長とその破壊が複雑に連成した問題で あることが明らかになっている。この酸化現象におい ては一般的に金属原子と外部から供給された酸素が結 合することから体積膨張が発生する．き裂の開口状態 に依存してこの体積膨張の拘束力が異なり, 酸化皮膜 内部の残留応力が変化すると, 酸化反応(すなわち酸 
化に寄与する原子拡散と界面反応) 速度にも変化が生 じ, 実質的なき裂進展速度にも変化が生じる可能性が ある.

地球温暖化防止対策として高温化が進められている ガスタービン翼系材料においても, 熱遮蔽コーティン グ膜内部の酸化膜の成長がその信頼性に大きな影響を 及ぼすことが知られている.この酸化膜の成長も高温 でかつセラミックと金属の固相界面という拘束された 環境における問題であり，かつ溶射法で形成されるセ ラミックや金属皮膜界面が平坦ではないことから，熱 応力や遠心力などが局所的に集中作用するため，その 成長速度は使用環境で大きく変化する可能性がある. 今後熱効率の向上を目的として機械的あるいは熱的負 荷が増加するとこの酸化膜の成長挙動もさらに加速さ れ, 製品寿命の著しい低下が懸念される.したがって, この応力依存の化学反応の加速あるいは減速現象は, 大型構造物の信頼性設計・評価においても重要な課題 となる可能性がある.

\section{5. 材料力学と計算力学の融合研究への期待}

ナノテクノロジーの進展はこれまでおもに述べてき た実験的研究にのみ依存しているわけではない. 並行 して原子レベルの解析技術が実用レベルに近づき始め ていることも研究全体の加速要因となっている。これ までの科学計算の世界で原子レベル解析の中心をなし てきたのは量子力学を基盤とした解析技術である第一 原理解析であった。本解析技術ではいわゆる材料定数 を使用しないため, 物理化学現象の本質解明に最も有 効な研究手段ではあったが, 解析規模が膨大になるこ とから数原子から十数原子規模からなる系の解析が限 界であり, 不純物や格子久陥あるいは結晶粒界が物性 の支配因子となる実用材料の解析は困難であった.

しかし，この第一原理解析を原子間の結合エネルギ 一解析に応用したニュートンの運動方程式に基づく分 子動力学解析が原子レベルでの定量的な現象解明解析 に活用でき始めており, 一千万原子規模の解析も可能 になりつつある.このため, 分子動力学解析技術を応 用して材料強度や破壊現象の解明研究が進められてい る. 特に共有結合やイオン結合など原子間の電荷 (電 子)移動も考慮した解析が可能となったことにより, 化学反応解析も視野に入り, 解析可能な現象が飛躍的 に増加している(18).

材料力学あるいは計算力学分野における分子動力学 の応用事例で最も多いのは材料中のき裂の発生あるい は進展解析である.さらに, 異種材料界面における接 着強度の定量的な解析も可能になりつつある ${ }^{(19)}$. ま
た, 薄膜の堆積過程における真性応力の発生メカ二ズ 厶を検討した報告(20)もあり, 今後の発展が期待され ている. 特に応力依存の化学反応解析などの分野では さまざまな融合研究を考えることができる，応力腐食 割れに基づくき裂進展解析などは最も重要な応用問題 であろう. 原子の拡散挙動に基づく材料の損傷や劣化 の進展解析も重要な課題である. 特に微細組織の変化 を伴う高温の疲労やクリープ損傷メカニズム解明研究 なども重要な研究課題になるものと考えられる ${ }^{(21)}$. 特に多元素系合金の信頼性解析では, 材料の各機能や 性能に及ぼす各添加元素の作用と副作用解析が同時に 可能になれば材料設計技術が飛躍的に向上するものと 考えられる.このためには数億原子以上を対象とした 大規模解析技術の開発も重要な課題となるであろう. また，このような原子レベル解析と従来の有限要素法 解析を統合したナノ領域からメガ領域までを一貫して 解析する融合問題解析技術の開発も重要な課題になる ものと期待される.

\section{6. おわりに}

ナノテクノロジーの進展に伴い材料力学の分野にお いてもまったく新しい研究課題, あるいは古くて新し い研究課題が山積している状況を簡単に紹介した．原 子レベルにおける物理化学現象の本質解明研究は, ま さに複数異分野領域にまたがる融合研究そのものであ り，学術的な相互理解が飛躍的に進歩するものと考え られる. 産業界のニーズも大きいので, 多くの若い研 究者の参入により, 材料力学研究が改めて発展するこ とを期待する.

\section{文献}

(1) International Technology Roadmap for Semiconductors 2005, (2005).

(2) Yu, M., et al., Tensile loading of ropes of single wall carbon nanotubes and their mechanical properties. PHYSICAL REVIEW LETTERS, Vol.84, No. 24 (2000), pp. 5552-5555.

(3) Salvetat, J., et. al., Mechanical properties of carbon nanotubes, Applicd Physics A-Materials Science \& Proccssing, Vol. 69, No. 3 (1999), pp. 255-260.

(4) Kiuchi, M., et. al., Development of On-chip Micro Tensile Testing Device for Mechanical-Electrical Characteristics of Carbon Nanowires, Proc. of Mechanical Engineering Congress, 2004 Japan, Vol. 1 (2004), pp. 367-368.

(5) Miura, H., Residual Stress of Thin Films, J. of Japanese Socicty of Tribologists, Vol. 40, No. 3 (1995) pp. 228-233.

(6) Inoue, A., Stabilization of metallic supercooled liquid and bulk amorphous alloys, ACTA MATERIALIA, Vol. 48, No. 1 (2000), pp. 279-306.

(7) Carsley, J., et. al., Mechanical behavior of a bulk 
nanostructured iron alloy, Mctallurgical and Materials Trans. A-Physical Metallurgy and Materials Science, Vol. 29. No. 9 (1998), pp. 2261-2271.

(8) Kito, H., et al., Development of Micro Fatigue Tester Based on AFM Technique for MEMS Materials, Proc. of Mechanical Enginecring Congress, 2004 Japan, Vol. 1 (2004), pp. 371-372.

(9) Ohmi, T., Process and Materials of Scmiconductor Equipment. (2005), CMC Publishing CO., LTD.

(10) Sakutani, K., et al., Mechanical Properties of Copper Thin Films used for Interconnection Structures, Proc. of 15th Microclectronics Symposium 2005, (2005), pp. $97-100$.

(11) Ogi. H., et al., Advanced resonant ultrasound spectroscopy for measuring anisotropic elastic constants of thin films, Fatigue Fract. Engng. Mater. Struct., Vol. 28 (2005), pp. 657-663.

(12) Miura, H., et al., Crystallization-induced Stress in Amorphous Silicon Thin Films, Trans. of the Japan Socicty of Mechanical Engineers, Vol. 58, No. 554-A (1992), pp. 1960-1965.

(13) The Physical Society of Japan, Physics and Application of Semiconductor Superlattices, (1984), pp. 210-233, BAIFUKAN CO.. LTD.

(14) Ghani, T., et. al., A $90 \mathrm{~nm}$ High Volume Manufactur. ing Logic Technology Fcaturing Novel $45 \mathrm{~nm}$ Gate Length Strained Silicon CMOS Transistors, 2003 IEDM Technical Digest, (2003), pp. 978-980.

(15) Miura, H. and Nishimura, A., Electronic Characteris- tics Changes of Semiconductor Devices Caused by Packaging Stress, Trans. of the Japan Society of Mechanical Engineers, Vol.61, No.589-A (1995) pp. 1957-1964.

(16) Kao, D. B., Two-dimensional Thermal-oxidation of silicon 2: Modeling stress effects in wet oxides, IEEE Trans. Electron Devices, Vol. ED-35, No. 1 (1988), pp. 25-37.

(17) Miura, H., et al., Residual Stress Measurement in Silicon Substrates after Thermal Oxidation, Trans. of the Japan Society of Mechanical Engineers, Vol. 58, No. 550-A, (1992) pp. 902-908.

(18) Miyamoto, A., et al., Atomic Processes in the Deposition and Sintering of Ultrafine Metal Particles on MGO (001) as Investigated by Molecular-dynamics and Computer"graphics, Applied Surface Science, Vol. 75 (1994), 51-57.

(19) Iwasaki, T. and Miura, H., Molecular dynamics analy. sis of adhesion strength of interfaces between thin films, Journal of Materials Research, Vol.16, No. 6 (2001) pp. 1789-1794.

(20) Moriya, H., et al., Analysis of Intrinsic Stress and Microstructure of $\mathrm{Si}$ Thin Films using Molecular Dynamics, Trans. of the Japan Society of Mechanical Engineers, Vol. 63, No. 613-A (1997), pp. 1999-2005.

(21) Miura, H., et al., Basic study of creep damage of $\mathrm{Ni}^{-}$ based superalloy by quantum chemical molecular dynamics analysis, Proc. of 55th Japan National Congress for Theoretical and Applied Mechanics (NCTAM) 2005, (2005), pp. 111-112. 